\title{
8: Evolving Education in Myanmar: the interplay of state, business and the community
}

\author{
Marie Lall ${ }^{1}$
}

\section{Introduction}

Historically, education has been seen as a tool of human-capital creation, especially in developing countries. The development theorists' case for compulsory education is based primarily on the link between mass education and economic growth (rates of return from education) as well as on the link between female education, fertility rates and public health. In short, the better educated a population, the healthier the population will be and the better developed the country will become. The role of the State has always been central in delivering education and the prime role of the state education system is to underpin the fulfilment of broader societal development goals. These goals could predominantly be economic, political, social or cultural, determined by the national, regional and international contexts. There is, therefore, an obvious need to adjust the content of education in a given context to changing societal conditions and needs over time. Underpinning the role of the State in education is the acceptance, since the end of World War II, of education internationally as a public good and the idea that the State has a responsibility towards its citizens in providing at least a basic level of education for all.

In today's globalising world, however, there is a shift away from perceiving education as a public good, as the private sector is increasingly involved in delivering education services (Ball 2007). Education reform, often pushed by the International Monetary Fund (IMF) and World Bank-sponsored structural reform programs in developing countries, is not necessarily focused on poverty reduction and universal access, but on making education a business like any other. The key World Trade Organisation (WTO) agreement for this purpose is the General Agreement on Trade in Services (GATS), which incorporates the aim of unleashing progressive liberalisation of trade in services, including public services such as education. The WTO 'education agenda' is to facilitate the penetration of education services by corporate capital. Education services are to be progressively commercialised, privatised and capitalised (Rikowski 2002, 2008). The WTO's view is that trade and investment liberalisation leads to more competition, greater market efficiency and so, necessarily, to a higher standard of living. Development, it is often argued, can be achieved most efficiently and 
effectively through private-sector involvement. The trend therefore is for increased privatisation/commercialisation of education, reducing state responsibility vis-à-vis its citizens.

In practice, however, standards of living for many countries in the developing world (with the exception of China) have declined absolutely or relatively (compared with the richer developed nations) in recent years (Chen and Ravallion 2007). The education issues that have emerged in developing countries due to globalisation are access to education and the digital divide, the commodification of education through privatisation, 'brain drain' and the threat to the autonomy of nations for educational systems. While increasing private-sector involvement and privatisation is creating a two-track society within countries, it is increasingly also creating a greater divide between richer and poorer nations. Both these problematic trends weaken the State. Against this backdrop, how should we view private education and private-sector involvement in education in cases where the State is already weak and not capable of providing adequate education? This chapter tries to address the problematic issue of private education with regard to Myanmar, a country in which state education does not cover minimum societal needs and in which civil society (Lorch 2007) and private businesses have had to develop roles as alternatives.

The case of Myanmar is particularly interesting, as the standard of state education has declined markedly in the past few decades. At independence, Myanmar had the highest literacy rate in its own language across the former British Empire (Cheesman 2003). For many years, the level of education was one of the highest in Asia, prompting other Asian countries to see Myanmar as an example. Decades of under-investment and civil strife, however, resulted in the slow and steady decay of the state education system across the country. Despite the fact that school buildings continued to be built in cities and in villages during the socialist era, teacher education and teacher pay deteriorated markedly. The system has never recovered, and today Myanmar is facing an education crisis in its cities and in rural and tribal areas.

In many areas, monastic schools have increasingly come to underpin the state education system for the very poor. In tribal areas such as Kachin State, church organisations have played a similar, if slightly different role. With the advent of a small but increasingly affluent middle class, however, parents search for a third way to educate their children. Some of the very rich have sent their children to international/diplomatic schools or overseas, however, the middle classes do not have the means to follow suit. Consequently, in urban centres, a large number of unofficial schools in the private sector has sprung up teaching principally English and often other subjects as well. This is offered in addition to the state system, which remains compulsory. The cities, but Yangon in particular, are experiencing an increase in the development of edu-business. As a result, unlike 
in other developed and developing countries, the privatisation of education in Myanmar represents not so much a threat to the strengthening of a national education system, but an alternative for the small but growing middle class in the cities. This inevitably leads to a greater gulf between the urban elite and the wider, much poorer and often rural population. While the increased privatisation in most developing countries is to be deplored and increased marketisation is to be resisted by the government and parents, the case of Myanmar shows, however, that in this particular case private provision is one of civil society's responses to a state that no longer provides the minimum education needed by its citizens. This chapter will discuss how the private-sector schools are carving out a new space between state education and civil society/community organisations.

This chapter is based on a number of interviews and observations conducted during seven trips to Myanmar between 2005 and 2007. Most of the research was conducted in Yangon, but there was a field trip to Mitkyina (Kachin State) and the author also spent some time in Mandalay. A research assistant was employed to translate Burmese texts (newspapers and policy documents) and to collect data from the private schools in Yangon. ${ }^{2}$ The chapter discusses the interplay of the state and the private sectors and how these are creating a new dynamic in the education world of Myanmar. It will do so in the general context of increased privatisation in developing countries, arguing, however, that in Myanmar the increased private-sector involvement is not 'used' by the State to reduce state education. The chapter will also discuss the effects of such private involvement, which, as elsewhere, is increasing the divide between the emerging middle class and the broader and poorer population, who have no alternative to the state system.

\section{The issue of private-sector involvement - a global phenomenon}

The debate about education for profit is a contentious one, and one that has led to a large amount of research (see, among many others, Ball 2007). The traditional, and largely Western, post-World War II view has been that education is a public good and should not be manipulated for private benefit. It is largely argued in the literature that private companies should not be able to profit from government investment in education and also that they should not be able to shape the education that children receive in order to make more profit.

More recent trends in the West and in developing countries, however, show a major shift in attitude - at the state/government level as well as among the middle classes, especially in developing countries. The trend of allowing for more private education and the increasing demand coming from certain sections of society are of course congruous and largely a part of an increasingly globalised world. Contrary to expectations, even the poorest sections of society sometimes turn 
to private provision, in the hope of giving their children a better future. An example of this is private slum schools in India, where parents can barely afford the few rupees a day for school fees (see Srivastava 2008). This often results in the State abrogating its responsibilities, as the private and the not-for-profit sectors offer alternatives for different sections of society.

As mentioned in the introduction, the WTO facilitates globalisation through the opening up of all spheres of social life-including public services-to international capital. In effect, the WTO's education agenda is to facilitate the penetration of education services by corporate capital. The key WTO agreement for this purpose is the GATS. This agreement incorporates the aim of unleashing progressive liberalisation of trade in services, including public services such as education. In the long term, no area of social life is exempt from these developments.

The UN Development Program (UNDP 1999), however, and others have warned that globalisation is increasing the gap between the rich and the poor, between connected and isolated cultural groups and that inequality within countries has increased dramatically in the past 20-30 years. Global forces are also leading to increasing population movement and thus to an exponential increase in intercultural interactions and exchanges. Whereas globalisation is opening doors for a highly mobile, highly skilled international elite, it seems to be closing them for many others, who will either seek to escape or remain locked in poverty.

Consequently, the issue of private education and increased privatisation of state education is problematic. The phenomenon is also different from country to country. Whereas in the United Kingdom, for example, it is more a case of 'commercialisation' because the assumption is that the quality of public services will be improved through the introduction of practices and the ethos typical of commercial practice, in India on the other hand, it is more about 'marketisation', because what is happening is the opening up of markets in areas where services were formerly under state monopoly control. It is not, however, always as simple as that; some of these markets are being quite carefully shaped with limited private-sector involvement and close state control, while in other cases there is no state regulation whatsoever.

The debate universally is, however, summed up best by Hatcher (2001:58):

[T] he starting point has to be the recognition that there are two distinct logics at work. One is a logic of education, based on social and individual need, and notions of equity and democracy. The other is a logic of business, whose bottom line is profit. Not everything business wants to do is incompatible with education interests. But the logic of business is incompatible with the logic of education. 
The question with regard to Myanmar is how far these two distinct logics really contradict each other or whether private education is one of the ways forward in the current difficult situation.

\section{Education in Myanmar - past and present}

The debate about the purpose of education goes beyond the economic/development argument as all education systems have a political objective: aside from human-capital creation, one of the primary aims of education systems in modern states is, and has always been, the political socialisation of the young. Education systems, especially in Asia, have their origins in processes of state formation aimed either at fostering resistance to the encroachments of Western and/or Asian imperialism, or at furthering post-colonial nation building. Definitions of national identity and visions of nationhood are often popularised by governing elites. One can argue that education has been used as a political tool throughout the ages and across the whole world to define national identity and underlie the political rationale of regimes (Lall and Vickers forthcoming). This has also been the case in Myanmar, where, throughout the socialist period, but also beyond that, education has been used for political purposes, largely to underpin the regime in power (Zarni 1998).

Since the end of the socialist era, however, and the opening up of the economy (and to a more limited extent the country) in the late 1980s, an interesting interplay of issues can be observed: governmental control, under-investment in the social sphere and a society searching for alternatives. As in most dictatorships, one of the reasons the military government has been keen to retain control of education is largely because of the belief that an 'independent' way of thinking poses a direct challenge to them. One could question whether the under-investment in the education system was motivated by the politics of control - the military elite perhaps hoping that a less-educated population would pose less of a challenge. Due to its deterioration, however, Myanmar's education system has also become highly ineffective as a political tool. The interesting nexus here is between a policy of under-investment and a society that is looking for alternatives that could in effect threaten the State even more.

This section will briefly describe the background of education in Myanmar before moving on to the private supplements and alternatives that have started to emerge in urban areas.

\section{Background}

The British colonial period established three types of schools of which the two upper-tier types were used to train people to fill the lower and middle ranks of the colonial administration, as they taught in English. The schools that taught entirely in Burmese were, however, by far the majority of schools. In 1945, the Department of Education was formed under the British Government to implement 
the Simla Scheme of Educational Rehabilitation. The scheme was financed out of the military budget. At that time, 42 post-primary schools and 2060 primary schools were opened. The Education Reconstruction Committee of 1947 decided that Myanmar needed a homogeneous system of schools and that the education system had to be state provided and state controlled (Lwin 2000:5).

At independence, Myanmar had the highest literacy rate in its own language across the former British Empire. This was due not only to the Burmese schools, but largely to the monastic schools that had always played, and continue to play, a major role in educating the poorer sections of society (Lorch 2007). Today, Myanmar retains a very high literacy rate, with 89.9 per cent of adults and 94.5 per cent of youth considered literate (UNESCO 2007). These statistics, although from a UN agency, are difficult to verify, but anecdotal evidence in urban areas shows most people reading on public transport and kerb-sides. The issue of literacy levels is therefore to be questioned largely in the rural areas.

For many years, other Asian countries saw Myanmar as an example in education. Decades of under-investment and civil strife have today resulted in the slow and steady decay of the state education system across the country. Despite the fact that during the socialist era school buildings continued to be built in the cities and in the villages, ${ }^{3}$ teacher education and pay deteriorated markedly. It was also at this time that Burmese was made the medium for teaching at all schools, abolishing the colonial legacy of English schools for the elite. In higher education, however, this had repercussions as textbooks and other literature were not available in Burmese.

\section{The state of education today: some different perspectives}

During the State Law and Order Restoration Council (SLORC) period, all higher-education institutions were closed for years at a time. After the student protest of 1988, all universities were closed for two years. Another series of student strikes in 1996 and 1998 resulted in a further three years of closure. In Yangon, between 1988 and 2000, universities were closed for 10 out of 12 years. After the reopening of universities and colleges in 2000, the government relocated many universities to different sites and undergraduate programs were moved to campuses far away from any urban centre. Consequently, higher education by correspondence is taken up by those who cannot afford to live away from home. Keeping students away from cities is one of the ways the regime hopes to control any civil strife. Today, more than 700000 students attend the 156 higher-education institutions and there are 10000 teachers. A further 13000 students are enrolled in one or two-year business-related courses (Zaw 2008a). Appendix 8.1 describes the structure of educational institutions in Myanmar. 
Education, and especially higher education, is often criticised in the press in Myanmar and there is no doubt that it encounters problems. In a response to a critical Burma Digest article, however, Aung Kyaw Soe (2006) claimed:

It may more correct to assess that [the] Education system is polarised, some students achieve more than others, either because of affordability of family, luck or hard work but I think we are seeing more Burmese graduates with undergraduate education from Burma are doing well in good graduate schools and work place[s]. I know more than 500 Burmese engineers with their first degree in Burma and second or third degrees from good overseas graduate schools.

According to a 2007 Myanmar Times special issue on education, the government established a 30-year education development plan in 2001-02 in order to develop a 'learned society' for the knowledge age, with the expansion of schools as a priority. The number of schools is said to have increased to more than 40000 , catering to eight million students (Zaw 2008b). Problems remain, however, especially with regard to access, quality and retention.

According to Khin Maung Kyi et al. (2000:145), the primary enrolment ratio is high. Nevertheless, primary education faces two main problems: there are not enough schools (the numbers range from one school for five villages to one school for 25 villages in the border regions); and there is a high drop-out rate, estimated to be about 34 per cent. The authors also point out the high repetition rate in rural and urban areas. UNESCO statistics are more positive: net enrolment rates at the primary level are 100 per cent for girls and 98 per cent for boys; at secondary level, the figures dropped to 43 per cent for both genders in 2005, with 91 per cent of all children completing primary education (UNESCO statistics web site 2005). This is in stark contrast with the report from the UN International Children's Emergency Fund (UNICEF) in 1995 that states that about only 27 per cent of all children completed five years of primary schooling and only 1.8 per cent of those who entered primary school completed secondary school (UNICEF 1995).

Another set of figures on Burmese education (Achilles 2005) cited net attendance in primary schools at 82 per cent for both genders (from 1998 to 2002) and the number of students who reached class five at 60 per cent officially and unofficially, based on surveys, at 78 per cent (for 1997-2003). Only 41 per cent of boys and 38 per cent of girls (from 1998-2002), however, made it into secondary school. Anonymous interviews in Yangon with an education charity confirmed the high drop-out rates, explaining that children showed up for the first school day and that statistics were based on this, but that as soon as a few days into the school year children, especially in rural areas, stopped attending. In part, such drop-out rates are the result of the high direct costs of sending children to school (such as buying books and uniforms). In rural areas, this is 
compounded by the high opportunity cost for parents who need their children's help working. Although schooling is free in principle, parents are expected to contribute to the financing of education, as state expenditure on education as a share of gross domestic product (GDP) is decreasing (Kyi et al. 2000:147). Those who cannot afford to attend state schools go to monastic schools or forgo their education altogether. Monastic schools were outlawed in 1962 during the socialist period and were allowed to return only in 1993. Today, however, 1500 monastic schools have been recognised by the government, catering for 93000 children (Achilles 2005). In some cases, the building is provided by the State but parents have to pool their funds to pay for a teacher; this is especially the case in remote areas (Lorch 2007).

Jasmin Lorch has written about how community-based groups and especially monasteries have come to fill the void for poorer sections of society. She also focuses on the role played by non-governmental organisations (NGOs) in putting together informal education programs (Lorch 2007). Her paper, however, does not discuss the recent growing urban trend of private education, which caters to the middle and upper classes.

\section{Private education in Myanmar}

In the immediate post-independence period from 1948 to 1962, private and state education were accepted in basic and higher education. During the socialist era between 1962 and 1988, however, private institutions were eliminated and the State dominated. According to the Myanmar Government web site (<http://www.myanmar.gov.mm/Perspective/persp1998/9-98/edu.htm>):

$[\mathrm{T}]$ hough the private sector has not yet formally been granted a status of setting up Universities with privileges to confer degrees, it has increasingly played an important role in the education market in consonance with the adoption of market mechanisms in the country's economy. The Private Tuition Law of 1964 permits setting up of private schools to teach single subjects per se. Permission is not granted to set up private schools to teach the full curriculum.

Private schools, which emerged since the 1990s, have developed as businesses and are not necessarily regulated by the Ministry of Education. The Ministry of Education in fact expects all Myanmar children to be registered in state schools. Private provision is accepted only over and above state education, with the exception of international schools. Policy as to what can or cannot be taught in private schools seems to have been developed in the past few years as such provision has increased. In fact, such policies seem to change quite arbitrarily and without much warning. The larger schools that operate as registered businesses are less affected than the smaller community-based outfits, which do not have the same kind of recognised business status. 
Today, private schools have sprung up at pre-elementary, elementary, secondary and higher-education levels to cater to the popular demands of the market in English language, computing, accounting and business-related training. Some of them offer a wider curriculum, some focus on only a few subjects. Officially, private schools are not allowed to operate as an alternative to the state system - although there are a few that have a special status, such as the Yangon International School and the Diplomatic School in Yangon. These private organisations - sometimes calling themselves schools and sometimes education centres - are also engaged in preparing students for examinations held by overseas universities and professional institutes. Some schools are founded as a business company and some as a service company. Many insist on a low profile and many whom the research team wanted to interview refused to speak on the record. Only a few, such as the ones detailed in the Appendix (but not limited to these), will advertise widely and are accepted in some form and to some degree by the government. This is the case largely because children of government officials attend these schools.

The quality of the teaching and curriculum content varies from institution to institution and cannot be verified. The representative of the Summit International Centre, who was interviewed, said: 'Abroad they have organisations to control the private schools' quality. So private schools must try to meet the requirement of the standard of this organisation. We should also have an organisation like this here.'

There is also a distinction between private schools that act as supplementary schools at the primary and secondary levels and the post-secondary-level schools that prepare students for study abroad. A third category is international schools, such as the International, the Australian and the Diplomatic School in Yangon. Supplementary schools are the most common as children are expected to attend state schools. In fact, the State tries to regulate these schools by limiting the number of subjects they can teach.

\section{Primary and secondary supplementary schools}

On the author's first field trip to Yangon, for a conference in January 2005, I met a businessman who had set up a school that was teaching in English. The school was at the primary level only and was meant as a supplement to regular state-school attendance, teaching after official classes had ended. The school was located in the businessman's house in a residential area in central Yangon. It emerged during the next few meetings with other education specialists that such schools were common, but there were no official data about how many there were and what they taught. Interviews revealed that many taught only English, but an increasing number of schools offered a broader curriculum, some even employing English-speaking foreigners on an unofficial basis. A visit about six months later revealed that there had been a 'crackdown' on such schools and 
that they were now allowed to teach only English and computing/information technology (IT). The government was also trying to regulate this new market by dictating what fees the providers could charge, aligning them with the (very low) salaries teachers received in state schools. It emerged from interviews that, especially in secondary supplementary schools, under the heading 'English' a number of social sciences such as history was being taught, and that IT also meant maths and science. In this way, a fuller curriculum could be maintained. Official fees, of course, could be supplemented through black-market cash payments. A further closure of schools took place in May 2006, leaving only the elite schools that had direct support from the government (Burma Digest 2006). According to anecdotal evidence, however, between 2007 and 2008 large numbers of private schools seem to have reopened. Interviews across a number of schools with teachers, parents and principals revealed that the most important aspect of an expansion of the private-school system would be a change in government regulation, allowing for the full curriculum to be taught. Across the board, it was felt that what was needed most was clarification of the status of private education provision and clear directives on who was allowed to do what. The regulation was enforced mostly by school closures on an ad hoc basis. Apart from the elite schools operating as large businesses, there seems to be no dialogue between the stakeholders and any of the relevant ministries.

Despite the tight regulation on curriculum content, fees and teacher salaries, some larger consortiums have managed to set up private schools and education centres around the country. The International Language and Business Centre (ILBC) is such a venture and caters to a wide age group of students of English and other subjects. It is perceived as one of the most popular education institutions by the middle-class parents who were interviewed as a part of the research (Box 8.1).

\section{Box 8.1}

\section{ILBC new class opens in Taunggyi and Lashio (Shan States)}

According to the Managing Director, the International Language and Business Centre (ILBC), which has [the] most branches of private schools across the country and is based in Yangon, opened new branches in two cities Taunggyi and Lashio in the Shan States. They will accept pre school students up to GCE 'O' for summer course[s] and for regular classes. ILBC is the first one among the private schools in Yangon and has three branches in Yangon in Bahan, Tarmwe and Thingangyun with a total of 450 students.

Khit Myanmar Weekly, 17 March 2006, vol. 3, no. 25, p. 3. 
Some private schools also operate with the help of volunteers. According to an article by Mara Khine (2006), a school named 'Growing Together' and teaching in English opened in Tharkayta Township, a suburban area of Yangon. It is run by Ma Khine Zar, who has a Masters degree in international relations, with the help of a Swedish ex-medical student and four volunteers. The school caters to pre-elementary children and all students are aged from three to five years. Khine Zar said the reason why they opened the school was so that children could learn English early. At the time the article was published, they had 30 students. It was not clear from the article if the school levied fees.

Beyond ILBC - a business venture - and pre-elementary schools staffed by volunteers, there are also summer schools that run like a business. An example is the Summit International Learning Centre in Yangon (Box 8.2). According to Ni Ni Myint (2008), it is schools like these that have encouraged parents to turn to education as a means of creating a brighter future for their children.

\section{Box 8.2}

\section{English for skills priority summer school open}

The Summit International Learning Centre in Yangon will open a summer school from March 6 to May 26, 2006 said the principal of this centre. The school will train English for skills using 50 per cent school time. Moreover, it will arrange mental maths, science \& a social period. The summer courses are taken from International Courses which are specially made for summer class. The school will give original test books (not copied in Myanmar). There will be three separate classes for age groups between 4 to 12. There will be a school bus for the students. The school times are from 9 to 2:30. After the summer class, it will open for regular classes.

Khit Myanmar Weekly, 3 March 2006, vol. 3, no. 23, p. 2.

The Myanmar Marketing Research and Development (MMRD) publication called The Edge is a comprehensive listing of all educational institutions in Yangon, covering general education, language training, professional training and vocational training. Looking at the 2002 and 2007 versions, one can see a slight increase in institutional numbers (detailed in parenthesis in the following: 2002/2007). In the section entitled 'General education', the subheadings are 'Day care' (61/68), 'Kindergarten' (17/19), 'Pre-school' (89/100), 'Primary' (18/16), 'Secondary' (11 - for 2007 only), 'International schools' (11/12) and 'GCE'O'/SAT' (22). The total number in 2007 is 216 in Yangon alone. Other subheadings are 'Basic education schools' and 'Universities' and 'colleges' (these last categories are the government institutions). 
It is clear from the listings that most private institutions cater to the pre-primary age (which includes pre-school and kindergarten), nevertheless offering a variety of subjects such as Myanmar, English, maths and general knowledge as well as singing, playing and drawing. In certain cases, other languages such as Mandarin are also on offer. The day-care centres/kindergartens cater to those aged from three to five, but some offer their services from the age of one. The prices (for 2002) ranged from about 500-30 000 kyat a month. The older the children, the greater the variety of subjects taught (including IT, geography, history, science, arts, physical education, and so on) and the more expensive they are. The Montessori Children's House seemed at the time to be the most expensive pre-primary option, at 45000 kyat a month. Today, the fees are much higher, with the Summit International Learning Centre's fee set at 75000 kyat a month (Myint 2008). The parents, teacher and principals interviewed all accepted the fact that the private sector was available only to the upper echelons of society and some families in the middle classes who were prepared to spend between 25 and 50 per cent of their household income on fees. The representative of the Summit International Language Centre said in an interview that the school was offering its services at a reasonable price and tried to arrange lower fees for poorer parents ('Our school is sharing and caring'). The various interviews also revealed that parents chose schools on the basis of reputation and whether they employed foreign teachers. They saw the advantages for their children based mainly on the proficiency of English acquired in such schools as well as an education system more closely related to the exams needed to study abroad.

\section{International schools, pre-collegiate programs and higher education}

Aside from supplementary schools, there are other private education facilities. They are either international schools catering to the expatriate community and to some very rich Myanmar families or they are pre-collegiate and higher-education programs that help their students leave Myanmar to study abroad. The surge in the international education market started in Yangon in 1997, as middle-class parents wanted opportunities for their children to study abroad. Local entrepreneurs took risks by competing for contracts with overseas universities and colleges and by establishing private schools geared towards children who wanted to study overseas.

Winston Set Aung, a visiting lecturer in the Management Business Administration program at the Institute of Economics, quoted in a Myanmar Times article, said there were qualified schools affiliated with famous overseas universities and colleges and unqualified schools that had linked up with unknown foreign universities:

It is very easy to make a profit this way, so that's why many private schools try to work as brokers with overseas schools. [However] let the 
buyer beware. With more regulation for private schools, parents will see a better value for their money, and unqualified schools will surely lose out. (Zaw 2005)

There are also private schools in Myanmar that teach the American or the British curriculum and offer international qualifications. These schools start accepting students at pre-kindergarten level and those who follow the American curriculum usually need to study up to grade 12. As for the schools that follow the British curriculum, they prepare students to be able to sit for GCSE exams after the completion of matriculation, which is offered by the British Council Exams Unit. According to an article in Khit Myanmar Weekly (2006), more and more Myanmar students enter the Cambridge University exam every year. In 2006, there were 30 students aged between nine and 13 who passed the exam. According to the British Council (<http://www.britishcouncil.org/eumd-informationbackground-burma.htm $>$ ), however, which is keen to market British higher education, the Myanmar Government does not encourage international education promoted by the private-education sector:

Education authorities assume that the [growth of the] private sector harms the image of state education and instead of improving their system they discourage the growth of the private sector. A few investors from the private education sector establish joint ventures with the Ministry of Education and only these ventures are free to promote their business under the umbrella of the education ministry.

The issue is particularly important in the higher-education sector, which used to be a beacon of excellence in Asia. Today, there are 156 higher-education institutions in Myanmar, of which 64 institutions are under the jurisdiction of the Ministry of Education (MoE) and 92 are under 11 other ministries and the Civil Service Selection and Training Board. All the higher-education institutions are state financed. After finishing their matriculation, most students will go to state universities or colleges for further studies. They do so at a comparatively young age, as they finish school at the age of 16 .

Due to the declining quality of the state education system, students and parents crave better qualifications and study opportunities abroad. This is, however, an option only for the rich and upper classes, who can afford to send their children abroad.

Although inflation in this country has been increasing year after year, wealthier parents have tried their best to enable their children to possess internationally recognised certificates. Middle class parents often make very considerable sacrifices to invest in their children's future. (<http://www.britishcouncil.org/eumd-information-background-burma.htm>) 
The main market for international qualifications and preparation for these courses exists principally in Yangon. Quite a number of education agents there represent a range of study destinations in Singapore, Malaysia, the United States, Australia, New Zealand and Canada. There is, however, no official agent association to regulate these agencies. Increasingly, institutions from Singapore, Malaysia, Australia and New Zealand have become competitors for UK and US qualifications. Most of their customers are those who have their UK or US student visas rejected or those who cannot afford the high cost of study options in the United Kingdom or the United States.

Recently, the Myanmar press seems to be more prepared to report about Myanmar students who pursue their studies abroad. The March 2008 special edition of the Myanmar Times focusing on education had a number of articles about studying abroad and also featured interviews with students based in Singapore. In fact, according to Winston Set Aung, the research director at the Asia Development Research Institute, Singapore is now the preferred destination. He said that students going abroad to further their education should not be viewed as a brain drain on Myanmar:

They will get international higher education experiences and good connections, which will be of benefit to our own country one day. Millions of Japanese and Chinese students have left their home countries to pursue higher education abroad. Today Japan and China are developing thanks to the combined strengths of their local graduates and those educated in the foreign countries. (Winston Set Aung cited in Kyaw 2008)

Australian universities also seem to be popular and the Yangon Institute for University Studies (YIUS) pre-university level studies centre has helped more than 30 students join Australian higher-education institutions (Thit 2008). They are not alone. Over the years, an increasing number of local professional training centres/institutions has come into the market, offering preparatory courses for UK/US exams and professional qualifications to thousands of students. The pre-collegiate program, based at the Diplomatic School in Yangon, is one such program. The program is organised by an American couple resident in Yangon cooperating with Myanmar teachers. The aims of the program as stated in the 2006-07 handbook are to help students develop their academic abilities so that they can gain acceptance to and possibly a scholarship from an American college or university or other English-speaking universities in the United Kingdom, Japan, New Zealand, Australia, Canada, Ireland, Singapore or the Philippines. The program promises to help with visa applications, prepare the student for life in a Western college environment and help with the planning of a career back in Myanmar. To this end, Teaching of English as a Foreign Language (TOEFL) training is included as well as a curriculum encompassing comparative 
philosophy and literature, modern world history, environmental biology, comparative life cycles and literature in the English language.

Others who might not be able to pay for such courses rely on private tuition. This, however, can be problematic, as the summary of an article from Living Colour Magazine describes (Box 8.3).

\section{Box 8.3}

\section{Private subject tuition are [sic] investigated}

Private subject tuition has been investigated in the 2006-2007 school year. This was announced on May 9, 2006 by No.3 Basic Education Department under [the] Ministry of Education. The township chief education officer is to instruct those who are providing tuition to apply to get permission to open the tuition class. The Township chief education officer has to report the tuition classes which are eligible within the rules and regulations of the above department. The officer also has to report the illegible tuition classes. If some problems occur and if he does not report them, he has to take responsible [sic] for all problems. The teachers from these tuition classes will be investigated too. If a school runs without permission, it will be terminated in accord with the law of 1984 Rules and Regulation of Private Subject Tuition.

Living Colour Magazine, vol. 132, July 2006, p. 18.

In hoping to give their children a better future with study options abroad, parents are also keen to send their children to formal institutions, although the quality of tuition is not verified or regulated. An article that appeared recently in the Voice weekly explains the situation (Box 8.4).

\section{Box 8.4}

\section{Private schools ending with 'School' chosen over those that end with 'Centre'}

If the name ends with 'school', private schools are more likely to be chosen than if it ends with 'centre' said a principal of the private international school which opens in Yangon, Myanmar. The parents choose this as it is related with the international private school field. In this field, more credible names end with 'school' rather than having a name ending with 'centre'.

According to the same principal over ninety per cent of parents did not check the credibility of the school. These parents send their children to what was perceived as popular schools [sic]. 
Until recently there were just two private schools (the most famous) - whose names end with 'school' - they are Yangon International School (Shwe Taung Gyar Street, Bahan Township, Yangon) and the Diplomatic School (Shin Saw Pu Street, Sanchaung Township, Yangon).

The Voice Weekly, vol. 3, no. 30, 7 May 2007, p. 8.

\section{Outside Yangon in an ethnic minority area: the case in Mitkyina}

The situation in Yangon is atypical of Myanmar in general. While there are similar trends to be observed in Mandalay, other state capitals have fewer alternatives to offer to the failing state system. On the Shan-China border, the author observed a number of Chinese schools. It was, however, not clear from interviews if the parents sent their children only to these schools instead of government schools, or if these were supplementary schools. What was clear was that parents had to pay for the schooling and for the books.

In Kachin State, various Christian churches supplement a large part of education. They see this as essential as the Myanmar system is based largely on Buddhist principles, while a large number of Kachin are Christian or animist. 'Private schools are not allowed, but when they [are] we will make it cheaper than going to state school,' one reverend said.

Some theology students and high-school teachers run a series of programs on a voluntary basis. They offer education and exam training to those who cannot afford the books and uniforms for the state-run schools. The program covers a maximum of four years and is offered in three centres across Kachin State. The students can then pass the matriculation exam that is offered in the tenth standard, which allows them to enrol at the higher-education level, mostly through the distance-learning programs.

Other supplementary schools operate on a more informal basis and are there primarily to help children understand and know their Kachin heritage. Kachin leaders who were interviewed differed in their views of how much of a threat the increasing Chinese influence was to their Kachin and Christian cultures. One interviewee in particular saw Chinese help as something that would counteract the Bamar influence, which was still perceived as the product of an occupying power. The fact that the Chinese language was becoming the choice par excellence for most parents was seen as a small price to pay. Another interviewee, however, viewed the Chinese influence with suspicion and said that unless a Kachin Christian school was allowed to operate instead of the state school, parents would start to choose Chinese alternatives. The people interviewed were interested particularly in raising funds to expand their Kachin cultural education. One of 
the members of the group wanted to cover a full and comprehensive curriculum so as to develop an alternative to the state system once such a thing was allowed. Interestingly enough the one 'private' option that exists in Mitkyina is a Chinese school and college funded by the Taiwanese Government. So close to the Chinese border and with a number of trade routes linking Kachin State with Yunnan Province, one would have expected Chinese schools to have been set up, just as in Shan State. This was, however, not the case. As the Chinese language is becoming increasingly important for trade purposes and consequently more popular with parents, parents are sending their children to the Taiwan-funded school for their language training.

The connection between the Kachin and the Chinese is stronger than with their other neighbour, India. One church leader who was interviewed said that India's influence economically and in the education sector was negligible, but that higher education in India was still seen as higher quality than the Chinese alternative and that those who could do so would cross the border to study in India at a higher-education level.

\section{Conclusion}

The deterioration of Myanmar's education system underlies the low economic growth of the country. The economic side of Myanmar's education story is not one that is hard to tell. As Lorch has stated, civil society has jumped in where possible, but without managing to replace the State in any significant way. One particular section of civil society, the private sector, has used this business opportunity to turn education into a private and profitable good. The interesting fact is that the increased private schooling is fuelling the gap in Myanmar's authoritarian logic. The regime has let institutions decay and has not provided the resources needed to build a strong state education system. This is a short-sighted tactic, as it in effect loosens the regime's control over society. The private sector's education aims are profit, but they achieve this by encouraging an education system meant largely to help children leave Myanmar and study abroad. Currently, education in English is the most desirable education parents can acquire for their children. As this trend continues, the regime is allowing a condition that increases the absence of its legitimacy, because it equates good education with foreign education. This problem goes beyond civil society simply patching up an inadequate or insufficient social structure. 


\section{References}

Achilles, J. 2005, 'Das Bildungswesen in Birma/Myanmar-Erfahrungen zum Engagement im Bildungsbereich', in U. Bey (ed.), Armut Im Land der Pagoden, Focus Asien nr. 26, $<$ http://www.asienhaus.de/public/archiv/focus26-031.pdf>

Ball, S. 2007, Education PLC, Routledge, London.

Cheesman, N. 2003, 'School, state and Sangha in Burma', Comparative Education, vol. 39, no. 1, February, pp. 45-63.

Chen, S. and Ravallion, D. 2007, Absolute poverty measures for the developing world 1981-2004, World Bank Policy Research Working Paper 4211, $<$ http://www-wds.worldbank.org/servlet/WDSContentServer/WDSP/IB/2007/04/ 16/000016406_20070416104010/Rendered/PDF/wps4211.pdf>

Crouch, C. 2003, Commercialisation or Citizenship? Education policy and the future of public services, Fabian Society, London.

Hatcher, R. 2001, 'Getting down to business: schooling in a globalised economy', Education and Social Justice, vol. 3, no. 2, pp. 45-59.

Khine, Mara 2006, 'Learning English young', Ku Mu Dra Journal, no. 208, 10 February 2006, p. 9.

Khit Myanmar Weekly 2006, vol. 3, no. 19, 3 February 2006, p. 5.

Kyaw, Htin 2008, 'Human capital to be developed, not copied', Education-The Key to The Future, Myanmar Times Special Issue, 2-9 March 2008.

Kyi, Khin Maung, Findlay, Ronald, Sundrum, R. M., Maung, Mya, Nyunt, Myo, Oo, Zaw et al. 2000, Economic Development of Burma: A vision and a strategy, Olof Palme International Centre, Stockholm.

Lall, M. and Vickers, E. (forthcoming), Education as a Political Tool in Asia, Routledge, London.

Lorch, Jasmin 2007, 'Myanmar's civil society - a patch for the national education system? The emergence of civil society in areas of state weakness', SÜDOSTASIEN aktuell, issue 3/2007, pp. 54-88.

Lwin, Thein 2000, Education in Burma (1945-2000), chapter 3, $<$ http://burmalibrary.org/docs/Education_in_Burma_(1945-2000).htm>

Myint, Ni Ni 2008, 'Summer schools first step on path to brighter future', Education - The Key to The Future, Myanmar Times Special Issue, 2-9 March 2008.

Rikowski, G. 2002, Globalisation and education, Paper prepared for the House of Lords Select Committee on Economic Affairs, Inquiry into the Global 
Economy, 22 January,

<http://www.leeds.ac.uk/educol/documents/00001941.htm>

Rikowski, G. 2008, Globalisation and education revisited,

$<$ http://journals.aol.co.uk/rikowskigr/Volumizer/entries/2008/03/02/

globalisation-and-education-revisited/1737>

Soe, Aung Kyaw 2006, 'A peep behind the curtain of Myanmar education system', Burma Digest, 5 June, <http://burmadigest.wordpress.com/2006/06/05/ a-peep-behind-the-curtain-of-myanmar-education-system $/>$

Srivastava, P. 2008, 'School choice in India: disadvantaged groups and low-fee private schools', in M. Forsey, S. Davies and G. Walford (eds), The Globalization of School Choice, Symposium Books, Didcot, Oxon.

Thit, Aye Thawada 2008, 'Myanmar students choosing Australian and Singapore unis', Education - The Key to The Future, Myanmar Times Special Issue, 2-9 March 2008.

United Nations Development Program (UNDP) 1999, Human Development Report: Globalization with a human face, Oxford University Press, New York, <http://hdr.undp.org/en/reports/global/hdr1999/>

United Nations Educational, Scientific and Cultural Organisation (UNESCO) 2007, Statistics web site, <https:/portal.ioe.ac.uk/http/stats.uis.unesco.org/ unesco/TableViewer/document.aspx?ReportId=121\&IF_Language=eng \&BR_Country $=1040>$

United Nations International Children's Emergency Fund (UNICEF) 1995, Children and Women in Myanmar: A situation analysis, United Nations International Children's Emergency Fund, Yangon.

Zarni 1998, Knowledge, control, and power: the politics of education under Burma's military dictatorship (1962-88), Unpublished thesis, University of Wisconsin, Madison.

Zaw, Minh 2005, 'Interest in overseas education rises', Myanmar Times, 8-14 August 2005.

Zaw, Minh 2008a, 'HR key to development', Education - The Key to The Future, Myanmar Times Special Issue, 2-9 March 2008.

Zaw, Minh 2008b, 'Education system set to create learned society', Education-The Key to The Future, Myanmar Times Special Issue, 2-9 March 2008.

Translated articles from Myanmar newspapers and magazines such as:

Living Colour 2006-07.

The Voice 2006-07. 
Ku Mu Dra Journal 2006-07.

Khit Myanmar 2006-07.

\section{Appendix 8.1 Structure of educational institutions in Myanmar}

The Myanmar education system is governed through five departments - the Department of Basic Education, the Department of Higher Education, the Myanmar Examination Board, the Myanmar Education Research Bureau and the Myanmar Language Commission - which are each led by a director-general or equivalent. There is also a Council of the Universities Academic Bodies and a Universities Central Administrative Council.

Basic education is divided into the normal mainstream as well as technical and vocational education. The time a child spends in the normal stream is five years in primary, four years in lower secondary and three years in upper-secondary levels. According to government data, there were 7.2 million students with 224 000 teachers and 38800 schools in 1996-97. For technical and vocational education, there are seven state agricultural institutes, 17 technical high schools, 10 agricultural high schools, three commercial schools, two machinery repair and maintenance schools, 11 handicraft schools, six schools of home sciences and two schools of fishery - a total of 58 in 1996-97. There are five teacher-training colleges, 14 teacher-training schools and three correspondence courses for training various levels of basic education teachers. Today, there are 38 universities, one management college and five degree colleges (<http://www.myanmar-education.edu.mm/moe_main/index.php $>$ ).

\section{Appendix 8.2 Examples of private schools in Yangon}

\section{Horizon International Education Centre}

Level/grade: from Nursery GCE A level

Number of students: more than 100 in every year (local and international students)

Number of teachers (total): 24

Local teachers: 14

Foreign teachers: 10

Education system (British, US or other): combined US and British system Medium of instruction (English or Myanmar): English

Aids, tools and activities: computer, arts, gym, swimming pool (at Hotel Nikko Royal Lake), school bus.

Foundation year (head office/main campus): 2000/Yangon 
Address: No. 21, Pho Sein Street, Bahan T/S, Yangon

Telephone: 72 8016, 543926

Web site: www.horizon.com.mm

Email: contact@horizon.com.mm

Campuses: Horizon Main Campus (Yangon), Horizon (KG I) (Yangon), Horizon (KG II) (Yangon), Horizon (Mandalay).

\section{International Language and Business Centre (ILBC)}

Level/grade: pre-school to GCE 'O' level

Number of students: 450 (local and international students)

Total staff (teachers and others): 270

Founder: U Tin Maung Win, from Myanmar

Education system (British, US or other): using international system and own system written by local experienced teachers.

Examination system: Common Assessment Test (exam plus activities in class and school).

Aids, tools and activities: computer, arts, gym, library, canteen, swimming pool, school bus.

Foundation year (head office/main campus): 1995 March/Yangon

Email: info@ilbc.net.mm

Campuses: Bahan, Tarmawe, Thingangyun (Yangon), Mandalay, Taungoo, Myitkyina (Kachin State), Lashio, Taunggyi (Shan State).

\section{Summit International Learning Centre}

Level/grade: junior nursery to kindergarten (primary class to open in 2007-08 school year).

Student age: two to six for regular classes (from ages four to 14 for weekend English classes).

Number of teachers (total): 13 (local and foreign)

Founder: Daw Win May Than, from Myanmar

Principal: Daw Win May Than

Education system (British, US or other): British

Aids, tools and activities: arts, swimming pool (at Summit Park View Hotel), school bus, outdoor activities.

Foundation year (head office/main campus): August 2006/Yangon 
Address: No. 248, Ah Lone Road, Dagon T/S, Yangon

Telephone: 72 2661, 725718

Web site: www.summit.bravehost.com

Email: summitilc@praize.com

\section{Nelson International Education Centre}

Level/grade: pre-school (primary school will open in 2008-09 school year).

Student age: three to five.

Number of students: 60

Number of teachers (total): 12

Principal: Daw Myat Thin Zar Htun

Foundation year (head office/main campus): September 2006

Address: No. 3, Tha Pyay Nyo Street, Sanchaung T/S, Yangon

Telephone: 510612

Web site: www.nelc-centre.com

\section{Ayeyarwady Media Service}

Level/grade: IELTS preparation courses and TOEFL (this school started offering English classes at basic, intermediate and premeditate levels. It also offers a Singapore polytechnic preparation course and sends students' applications to Singapore polytechnics. Cooperates with Temasak Polytechnic in Singapore, teaching Temasak's first-year business course. Qualified students from this school can receive a school grant from the Singapore Government.

Foundation year: July 2002

Consultant: retired professor of English Department of Yangon University

Course manager: retired associate professor (English Department of Yangon University)

Number of students: 17 last year; 36 this year (15 students now attending second-year course in Temasak, Singapore, among whom 10 receive grants and five pay their own expenses).

Target students: those from middle-class and higher-class families - especially students who want to study abroad but have not qualified with high enough scores, and whose parents can afford to pay for them.

\section{Endnotes}

${ }^{1}$ I would like to thank my Burmese research assistant, Thiri Zaw, who helped collect primary and secondary data in Yangon for this research project. 
2 There is very little material on education in Myanmar available and this chapter reflects the paucity of resources in that it cannot often cite other research. A lot of what has been documented here stems from the interviews conducted in the field and informal conversations with Myanmar citizens-some but not all of whom were education specialists.

3 This was the time of education expansion in physical terms as many new schools were opened and the number of university students increased rapidly. 